\section{Salinity Affects Growth, Yield and Elemental Concentration of Fennel}

\author{
A. Graifenberg, L. Botrini, L. Giustiniani, and M. Lipucci Di Paola \\ Dipartimento di Biologia delle Piante Agrarie, Università di Pisa, Viale delle \\ Piagge, 23, 56124 Pisa, Italy
}

Additional index words. Foeniculum vulgare, salt sensitivity, water and soil salinity, ion distribution

\begin{abstract}
Monte Bianco' and 'Everest' fennel (Foeniculum vulgare Mill.) were grown in $157-\mathrm{L}$ plastic pots and irrigated with water containing $\mathrm{NaCl}$ at $0,0.25,0.5,1.0,1.5,2.0$, or $2.5 \mathrm{~g} \cdot \mathrm{L}^{-1}$. The salt-tolerance threshold for yield was expressed as electrical conductivity of irrigation water (ECi) and saturated soil extract (ECe). ECi was $1.15 \mathrm{dS} \cdot \mathrm{m}^{-1}$ for both cultivars and ECe was 1.51 and $1.47 \mathrm{dS} \cdot \mathrm{m}^{-1}$ for 'Monte Bianco' and 'Everest', respectively. The thresholds for plant fresh weight were the same as yield. Below the threshold the average bulb yields were $265 \mathrm{~g} /$ plant in 'Monte Bianco' and $284 \mathrm{~g} / \mathrm{plant}$ in 'Everest'. Relative yields were reduced $18.9 \%$ and $17.8 \%$ for $\mathrm{ECi}$ and $15.7 \%$ and $14.3 \%$ for $\mathrm{ECe}$ for each unit increase above the threshold in 'Monte Bianco' and 'Everest', respectively. Sodium concentration was higher in bulbs in comparison with other tissues at all salinities. Bulb Na concentration increased to $3 \mathrm{dS} \cdot \mathrm{m}^{-1}$, reaching 1835 and $1866 \mathrm{mmol} \cdot \mathrm{kg}^{-1} \mathrm{dry}$ weight in 'Monte Bianco' and 'Everest', respectively. Chloride concentration had similar tissue distribution and trend as $\mathrm{Na}$. Potassium concentration in bulbs decreased with increasing Na concentration, while it remained constant in the other organs. Calcium concentration was not affected by salinity. Thus, fennel is sensitive to salt stress, lacking mechanisms for controlling ion influx into plant tissues, and is unable to cope with saline sodic environments.
\end{abstract}

Fennel is a biennial crop that is native to the Mediterranean region. Italy is the leading producer with $400,000 \mathrm{t}$ on 18,000 ha (Istituto Nazionale di Statistica, 1995). The marketable product is the bulb, which consists of the modified basal part of leaf petioles (sheaths).

Coastal salinity and accumulated salt in irrigated soils are becoming factors depressing yields of vegetable crops in Italy (Graifenberg et al., 1993). The direct effects of excess salt on plant growth may be ascribed to 1) an osmotic stress, with an increasingly negative osmotic potential of the soil solution that reduces water availability; 2) an ion imbalance stress; 3 ) a specific ion toxicity of $\mathrm{Na}^{+}$ or $\mathrm{Cl}^{-}$(Dudley, 1994). The effects of salt on most vegetable crops have been reported (Maas and Hoffman, 1977), but there is little information on fennel. Mangal et al. (1986) reported reduced fennel seed production with increased salinity. Therefore, an investigation was conducted to identify the salt-tolerance threshold, expressed as electrical conductivity of irrigation water (ECi) and saturated soil extract (ECe), for fennel bulb yield and plant fresh weight.

\section{Materials and Methods}

Plant material. On 27 Aug. 1994, seeds of 'Monte Bianco' and 'Everest' fennel (Olter, Asti, Italy) were sown in polystyrene trays ( 160 cells, $18 \mathrm{~cm}^{3}$ ), one seed per cell, and filled

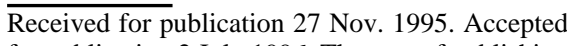
for publication 2 July 1996. The cost of publishing this paper was defrayed in part by the payment of page charges. Under postal regulations, this paper therefore must be hereby marked advertisement solely to indicate this fact.
$\mathrm{Mg}$, and $\mathrm{Na} / \mathrm{L}$, respectively. The $\mathrm{pH}$ was 7.4 and the ECe was $0.25 \mathrm{dS} \cdot \mathrm{m}^{-1}$. A 3-cm layer of expanded clay was placed at the bottom of each pot to ensure adequate drainage.

Pots were placed in a greenhouse covered with rigid polyvinyl chloride panels and without lateral walls. The mean day highs and lows in the greenhouse were 24 and $10^{\circ} \mathrm{C}$ in September and October, 13 and $5^{\circ} \mathrm{C}$ in November and December, 14 and $4{ }^{\circ} \mathrm{C}$ in January and February, and 17 and $8{ }^{\circ} \mathrm{C}$ in March.

Salt treatments. Plants were irrigated with rain water amended with $\mathrm{NaCl}$ at $0,0.25,0.5$, $1.0,1.5,2.0$, and $2.5 \mathrm{~g} \cdot \mathrm{L}^{-1}$. Rainwater electrical conductivity $(\mathrm{ECi})$ was $0.15 \mathrm{dS} \cdot \mathrm{m}^{-1}$. A soluble fertilizer $\left(20 \mathrm{~N}-8.7 \mathrm{P}-16.7 \mathrm{~K}, 0.5 \mathrm{~g} \cdot \mathrm{L}^{-1}\right)$ was added to the irrigation water. $\mathrm{ECi}$ values for the $\mathrm{NaCl}$ treatments were $0.75,1.1,1.5$, $2.2,3.0,3.7$, and $4.4 \mathrm{dS} \cdot \mathrm{m}^{-1}$, respectively. When matric potential, indicated by tensiometers (Reich BSR Technik, Cologne, Germany) inserted for each treatment at depth of $25 \mathrm{~cm}$ (rooting zone), was lower than $-0.160 \mathrm{kPa}$, water was automatically supplied by trickle irrigation to constantly maintain the matric potential. Irrigation with saline water started immediately after transplanting.

The design was a randomized complete block with four pots per treatment replicated four times.

Soil testing. Electrical conductivity of the saturated soil extract (ECe) was determined before transplanting (18 Sept. 1994), during the growing period (12 Feb. 1995), and at the end of the harvest (25 Mar. 1995) for each treatment (Table 1). Three soil samples were taken from each of three pots per treatment and from different pots at each sampling date.

Data collection. Plants were harvested on 25 Mar., when bulbs of control plants reached marketable size, i.e., bulb $8 \mathrm{~cm}$ in diameter. Plants were lifted from the soil, shaken carefully, and roots washed to remove any remaining soil. The plants were partitioned into roots, bulbs, and leaves, and weighed. Bulb, root, and leaf samples for each treatment were ovendried at $70^{\circ} \mathrm{C}$ for 4 days and reweighed.
Table 1. Effects of water (ECi) and soil (ECe) salinity, expressed as electrical conductivity, on yield and fresh weight of two fennel cultivars.

\begin{tabular}{|c|c|c|c|c|c|}
\hline \multicolumn{2}{|c|}{$\mathrm{EC}\left(\mathrm{dS} \cdot \mathrm{m}^{-1}\right)$} & \multirow{3}{*}{$\begin{array}{c}\text { Yield } \\
\text { (g/plant) }\end{array}$} & & & \\
\hline \multirow{2}{*}{$\begin{array}{l}\text { Irrigation } \\
\text { water }\end{array}$} & \multirow{2}{*}{$\begin{array}{c}\text { Saturated } \\
\text { soil } \\
\text { extract } \\
\end{array}$} & & \multicolumn{3}{|c|}{ Fresh wt (g/plant) } \\
\hline & & & Leaf & Root & Whole \\
\hline & & \multicolumn{4}{|c|}{ Monte Bianco } \\
\hline 0.75 & 0.85 & 260 & 258 & 58 & 576 \\
\hline 1.10 & 1.45 & 269 & 267 & 60 & 596 \\
\hline 1.50 & 2.00 & 186 & 186 & 46 & 418 \\
\hline 2.25 & 3.10 & 146 & 145 & 41 & 332 \\
\hline 3.00 & 4.00 & 115 & 140 & 35 & 290 \\
\hline 3.75 & 5.10 & 86 & 101 & 32 & 219 \\
\hline 4.40 & 5.30 & 85 & 100 & 28 & 213 \\
\hline \multirow[t]{2}{*}{ Linear $^{2}$} & & $*$ & $* *$ & * & $* *$ \\
\hline & & Everes & & & \\
\hline 0.75 & 0.85 & 283 & 284 & 41 & 608 \\
\hline 1.10 & 1.45 & 285 & 287 & 42 & 614 \\
\hline 1.50 & 2.00 & 145 & 150 & 30 & 325 \\
\hline 2.25 & 3.10 & 145 & 148 & 30 & 323 \\
\hline 3.0 & 4.00 & 130 & 146 & 30 & 306 \\
\hline 3.75 & 5.10 & 103 & 114 & 28 & 245 \\
\hline 4.40 & 5.30 & 50 & 69 & 16 & 135 \\
\hline Linear $^{2}$ & & $* *$ & $* *$ & $* *$ & $* *$ \\
\hline
\end{tabular}

${ }^{2}$ Relationship, tested by regression analysis, between ECi levels and responses of each character.

${ }^{*}, * *$ Significant at $P \leq 0.05$ or 0.01 , respectively. 
The equation of Maas and Hoffman (1977) was used to determine plant bulb yield and fresh weight in response to electrical conductivity of irrigation water and saturated soil extract. Two intersecting straight lines were used: a horizontal line with zero slope and a concentration-dependent line plotting yield vs. salinity and whose slope indicates the yield reduction percentage per unit increase in salinity. The intersection point designates the threshold, i.e., the maximum water or soil salinity that does not reduce yield below that obtained under nonsaline conditions.

Tissue analysis. Dried tissues were ground, and 2-g samples were digested in $70 \% \mathrm{HClO}_{4}$ and concentrated $\mathrm{HNO}_{3}(1: 2 \mathrm{v} / \mathrm{v})$ for $\mathrm{Na}, \mathrm{K}$, and $\mathrm{Ca}$ determination. Sodium, $\mathrm{K}$, and $\mathrm{Ca}$ were then determined using atomic absorption. Chloride was measured by mercuric thiocyanate method (Zall et al., 1956), reading the absorbance at $455 \mathrm{~nm}$ with a 4DR/2000 spectrophotometer (Hach, Loveland, Colo.).

Statistical analysis. The relative yield and plant fresh weight (PFW) for any given water or soil salinity exceeding the threshold was calculated by the equation proposed by Maas and Hoffman (1977): $y=100-b(E c-A)$, where $\mathrm{y}=$ yield or PFW, A = salinity threshold, and $\mathrm{b}=$ slope. Data were subjected to regression analysis. Standard errors were calculated on the means of the $\mathrm{Na}, \mathrm{Cl}, \mathrm{K}$, and $\mathrm{Ca}$ contents, reported by diagrams (Jandel Scientific, 1986).

\section{Results}

Fresh weight. The same bulb yield threshold of $1.15 \mathrm{dS} \cdot \mathrm{m}^{-1} \mathrm{ECi}$ was obtained for both cultivars, while yield reductions were $18.9 \%$ and $17.8 \%$ per $\mathrm{dS} \cdot \mathrm{m}^{-1}$ for 'Monte Bianco' and 'Everest', respectively (Fig. 1). ECe yield thresholds were 1.51 and $1.47 \mathrm{dS} \cdot \mathrm{m}^{-1}$ for 'Monte Bianco' and 'Everest', respectively, while the yield reductions were $15.7 \%$ and $14.3 \%$ per dS.m ${ }^{-1}$ (Fig. 1). A $50 \%$ decrease in bulb yield occurred at 3.7 and $3.9 \mathrm{dS} \cdot \mathrm{m}^{-1} \mathrm{ECi}$ and at 4.7 and $4.9 \mathrm{dS} \cdot \mathrm{m}^{-1}$ ECe for 'Monte Bianco' and 'Everest', respectively (Fig. 1). Whole-plant fresh weight began to decrease at $>1.10 \mathrm{dS} \cdot \mathrm{m}^{-1} \mathrm{ECi}$ and $1.45 \mathrm{dS} \cdot \mathrm{m}^{-1} \mathrm{ECe}$ in both cultivars (Table 1). Plant fresh weight thresholds were the same as those of yields, whereas slopes were $17.3 \%$ and $16.9 \%$ per $\mathrm{dS} \cdot \mathrm{m}^{-1}$ of ECi and $14.4 \%$ and $13.5 \%$ per $\mathrm{dS} \cdot \mathrm{m}^{-1}$ of ECe for 'Monte Bianco' and 'Everest', respectively (Fig. 2).

Dry weight. A decline of dry weight in all tissues, particularly bulbs and leaves, was associated with increased salinity (Table 2). From 0.75 to $4.40 \mathrm{dS} \cdot \mathrm{m}^{-1} \mathrm{ECi}$, dry matter decreased $67.7 \%$ in leaves, $78.2 \%$ in bulbs and $59.8 \%$ in roots of 'Everest', and $54.6 \%$ in leaves, $63.4 \%$ in bulbs, and $42.6 \%$ in roots of 'Monte Bianco'. A rapid decrease in dry weight in both cultivars occurred at $>1.10 \mathrm{dS} \cdot \mathrm{m}^{-1} \mathrm{ECi}$.

Sodium, $\mathrm{Cl}, \mathrm{K}$, and $\mathrm{Ca}$ concentration. Sodium and $\mathrm{Cl}$ concentration of both cultivars was higher than that of the other elements analyzed. In both cultivars and at all ECi levels, the $\mathrm{Na}$ concentration was highest in bulbs (Fig. 3). Bulb Na concentration increased

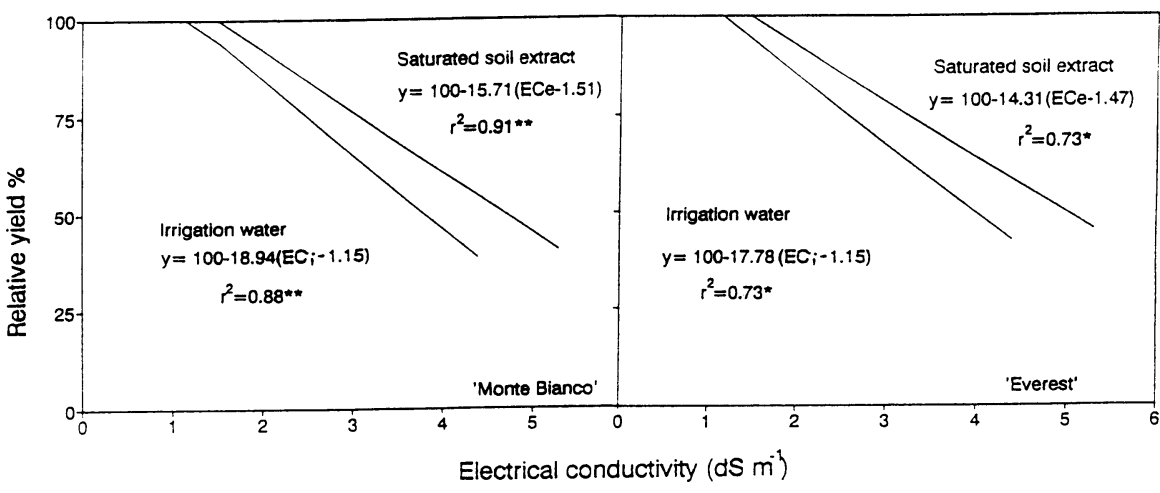

Fig. 1. Relationship between electrical conductivity of irrigation water (ECi) and saturated-soil extract (ECe) and relative bulb yield of two fennel cultivars.

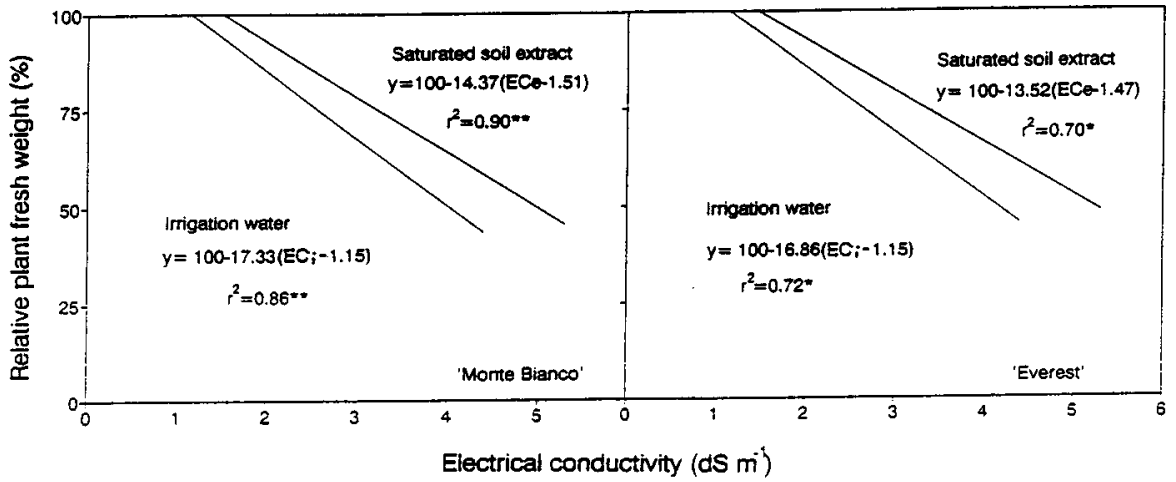

Fig. 2. Relationship between electrical conductivity of irrigation water (EGi) and- saturated-soir extract (ECe) and relative plant fresh weight of two fennel cultivars.

Table 2. Effects of water (ECi) and soil (ECe) salinity, expressed as electrical conductivity, on tissue dry matter of two fennel cultivars.

\begin{tabular}{|c|c|c|c|c|c|}
\hline \multicolumn{2}{|c|}{$\mathrm{EC}\left(\mathrm{dS} \cdot \mathrm{m}^{-1}\right)$} & & & & \\
\hline \multirow[b]{2}{*}{$\begin{array}{l}\text { Irrigation } \\
\text { water } \\
\end{array}$} & \multirow{2}{*}{$\begin{array}{c}\text { Saturated } \\
\text { soil } \\
\text { extract } \\
\end{array}$} & \multicolumn{4}{|c|}{ Dry wt (g/plant) } \\
\hline & & Bulb & Leaf & Root & $\begin{array}{r}\text { Whole } \\
\text { plant } \\
\end{array}$ \\
\hline \multicolumn{6}{|c|}{ Monte Bianco } \\
\hline 0.75 & 0.85 & 11.2 & 20.9 & 5.4 & 37.5 \\
\hline 1.10 & 1.45 & 11.3 & 22.2 & 5.6 & 39.1 \\
\hline 1.50 & 2.00 & 8.2 & 16.2 & 4.5 & 28.9 \\
\hline 2.25 & 3.10 & 6.4 & 12.9 & 3.7 & 23.0 \\
\hline 3.00 & 4.00 & 4.8 & 12.9 & 3.2 & 20.9 \\
\hline 3.75 & 5.10 & 4.7 & 9.5 & 3.2 & 17.4 \\
\hline 4.40 & 5.30 & 4.1 & 9.5 & 3.1 & 16.7 \\
\hline Linear $^{\mathrm{z}}$ & & $*$ & $* *$ & $* *$ & $* *$ \\
\hline \multicolumn{6}{|c|}{ Everest } \\
\hline 0.75 & 0.85 & 11.9 & 20.7 & 3.8 & 36.5 \\
\hline 1.10 & 1.45 & 12.0 & 20.9 & 4.0 & 36.9 \\
\hline 1.50 & 2.00 & 6.4 & 13.2 & 2.8 & 22.4 \\
\hline 2.25 & 3.10 & 5.9 & 13.0 & 2.8 & 21.7 \\
\hline 3.00 & 4.00 & 5.5 & 12.8 & 2.9 & 21.2 \\
\hline 3.75 & 5.10 & 5.4 & 10.5 & 2.7 & 18.6 \\
\hline 4.40 & 5.30 & 2.6 & 6.7 & 2.5 & 11.8 \\
\hline Linear $^{\mathrm{z}}$ & & $*$ & $* *$ & $*$ & $* *$ \\
\hline
\end{tabular}

${ }^{2}$ Relationship, tested by regression analysis, between ECi levels and responses of each character.

${ }^{*}, * *$ Significant at $P \leq 0.05$ or 0.01 , respectively.

from 1.1 to $3.0 \mathrm{dS} \cdot \mathrm{m}^{-1}$, reaching values of 1835 and $1866 \mathrm{mmol} \cdot \mathrm{kg}^{-1}$ dry weight in 'Monte Bianco' and 'Everest', respectively. Bulb $\mathrm{Na}$ concentration remained constant $>3.0 \mathrm{dS} \cdot \mathrm{m}^{-1}$. Sodium concentration of roots increased up to $3.0 \mathrm{dS} \cdot \mathrm{m}^{-1}$, reaching values of 1111 and 1302 mmol.kg ${ }^{-1}$ dry weight in 'Monte Bianco' and 'Everest', respectively. From 0.75 to $3.0 \mathrm{dS} \cdot \mathrm{m}^{-1}$ the increase in root $\mathrm{Na}$ concentration was 300 and $400 \mathrm{mmol} \cdot \mathrm{kg}^{-1}$ dry weight in 'Monte
Bianco' and 'Everest', respectively. Root $\mathrm{Na}$ concentration remained about constant $>3.0$ $\mathrm{dS} \cdot \mathrm{m}^{-1}$. Leaf tissue Na concentration increased only slightly with increased salinity.

The distribution and trend of $\mathrm{Cl}$ concentration (Fig. 4) among the fennel plant tissues were similar to those for Na. From 1.5 to 3.0 $\mathrm{dS} \cdot \mathrm{m}^{-1}, \mathrm{Cl}$ concentration of 'Monte Bianco' bulb and root tissues increased 900 and 450 $\mathrm{mmol} \cdot \mathrm{kg}^{-1}$, respectively. In contrast, $\mathrm{Cl}$ con- 
centration increase in leaf tissues was much smaller, especially in 'Monte Bianco'. Similarly to $\mathrm{Na}$ and $\mathrm{Cl}$, the major $\mathrm{K}$ accumulation organ was the bulb (Fig. 5). Potassium concentration decreased with increasing ECi in bulbs of both cultivars. At $4.4 \mathrm{dS} \cdot \mathrm{m}^{-1}$ the reduction in K concentration was $\approx 30 \%$ and $40 \%$ of the control in 'Monte Bianco' and 'Everest', respectively. Leaf and root K concentration did not vary significantly with ECi. Calcium concentration did not vary with ECi in any tissue (Fig. 6). In root tissue, Ca concentration was higher than in other organs, particularly in 'Monte Bianco'.

\section{Discussion}

Fennel would be considered salt-sensitive, similar to carrot [Daucus carota subsp. sativus (Hoffm.) Arcang.] and onion (Allium cepa L.) as reported by Maas and Hoffman (1977). Threshold and yield reduction depend on the irrigation system used. Growers most often use overhead sprinklers, which may induce large variations in soil water content. In our experiment, threshold and yield reduction values were obtained by using trickle irrigation controlled by a tensiometer, where a constant and high level of soil moisture was maintained.

Our data indicate that the root was less sensitive to salinity than the shoot, as also reported for other vegetables (Graifenberg et al., 1993, 1996; Lauchli and Epstein, 1990; Munns and Termot, 1986). The root : shoot ratio increased $63 \%$ and $85 \%$ for 'Monte Bianco' and 'Everest', respectively, as ECi increased from 0.75 to $4.4 \mathrm{dS} \cdot \mathrm{m}^{-1}$. However, the bulb was less salt tolerant, resulting in the largest fresh and dry weight reduction with increasing salinity.

Sensitivity to salinity appeared immediately after transplanting fennel, with a dramatic reduction in plant growth (data not shown). Reduced growth was likely caused by the high $\mathrm{NaCl}$ level increasing the osmotic potential of the circulating soil solution as well as by salt stress from excessive uptake of salt ions (Greenway and Munns, 1980). The ability of plants to produce and survive at high levels of salinity depends on the capacity to establish an equilibrated osmotic gradient between soil-root and shoot and to exclude salt ions from active plant tissues (Greenway and Munns, 1980).

The basal leaf part (sheath) that will form the bulb represents a very active plant tissue and was the site with the highest salt accumulation. Our data indicate that young sheath cells can not exclude $\mathrm{Na}$ and $\mathrm{Cl}$ ions from their metabolic pool.

Salinity often leads to an unfavorable uptake of cations (ion imbalance stress), inducing a reduction of $\mathrm{Ca}$ and $\mathrm{K}$ concentration in some species (Cramer et al., 1989; Francois et al., 1991; Graifenberg et al., 1995; Lynch and Lauchli, 1984). In fennel, Ca concentration was not affected by increased Na concentration, while $\mathrm{K}$ in the bulb decreased with increasing Na. Jeschke (1984) has reported a decline of K concentration in the Na-accumulating tissues

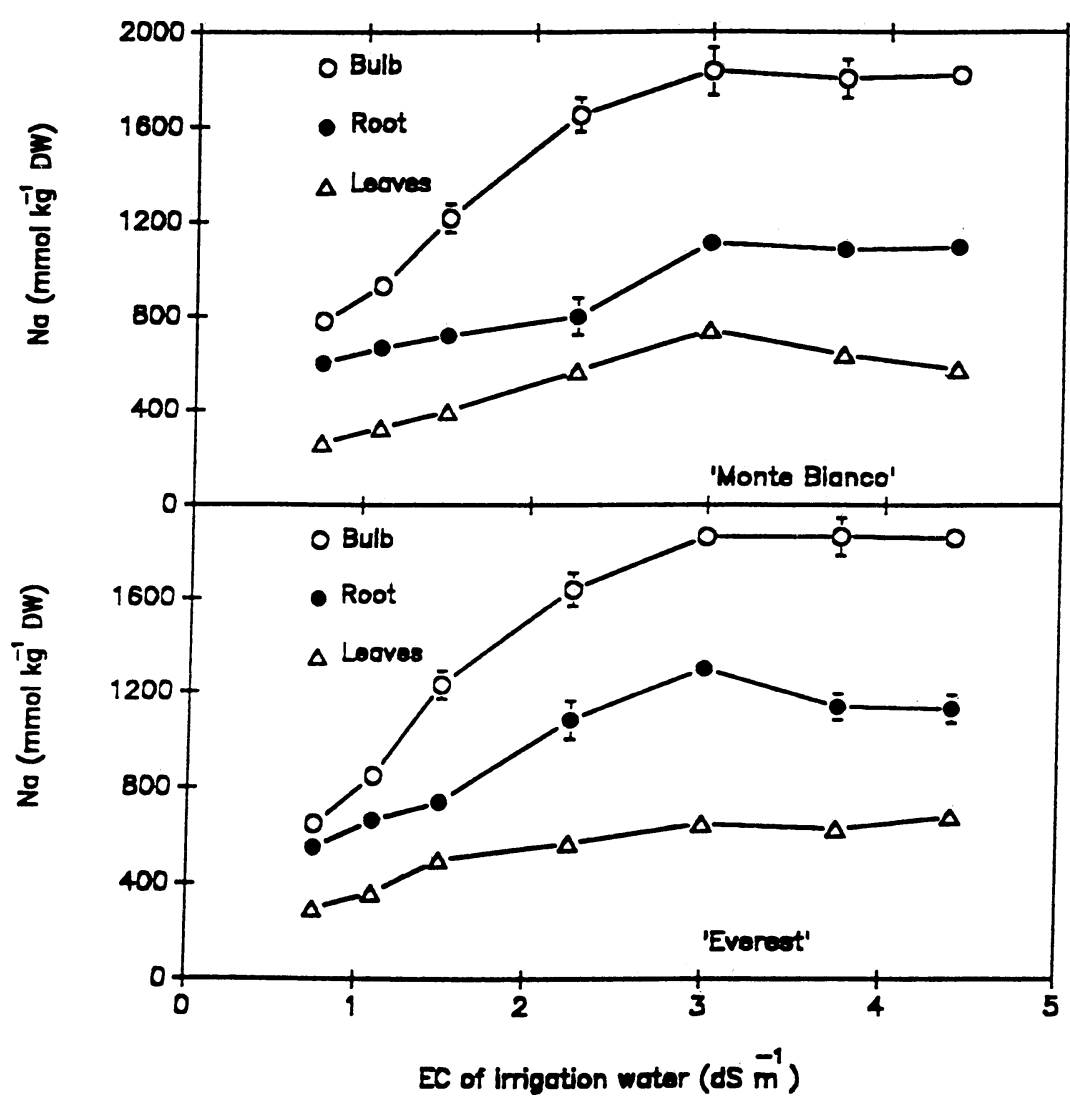

Fig. 3. Effects of electrical conductivity (EC) of irrigation water on Na concentration in three plant tissues of two fennel cultivars. Vertical bars indicate standard error of the means.

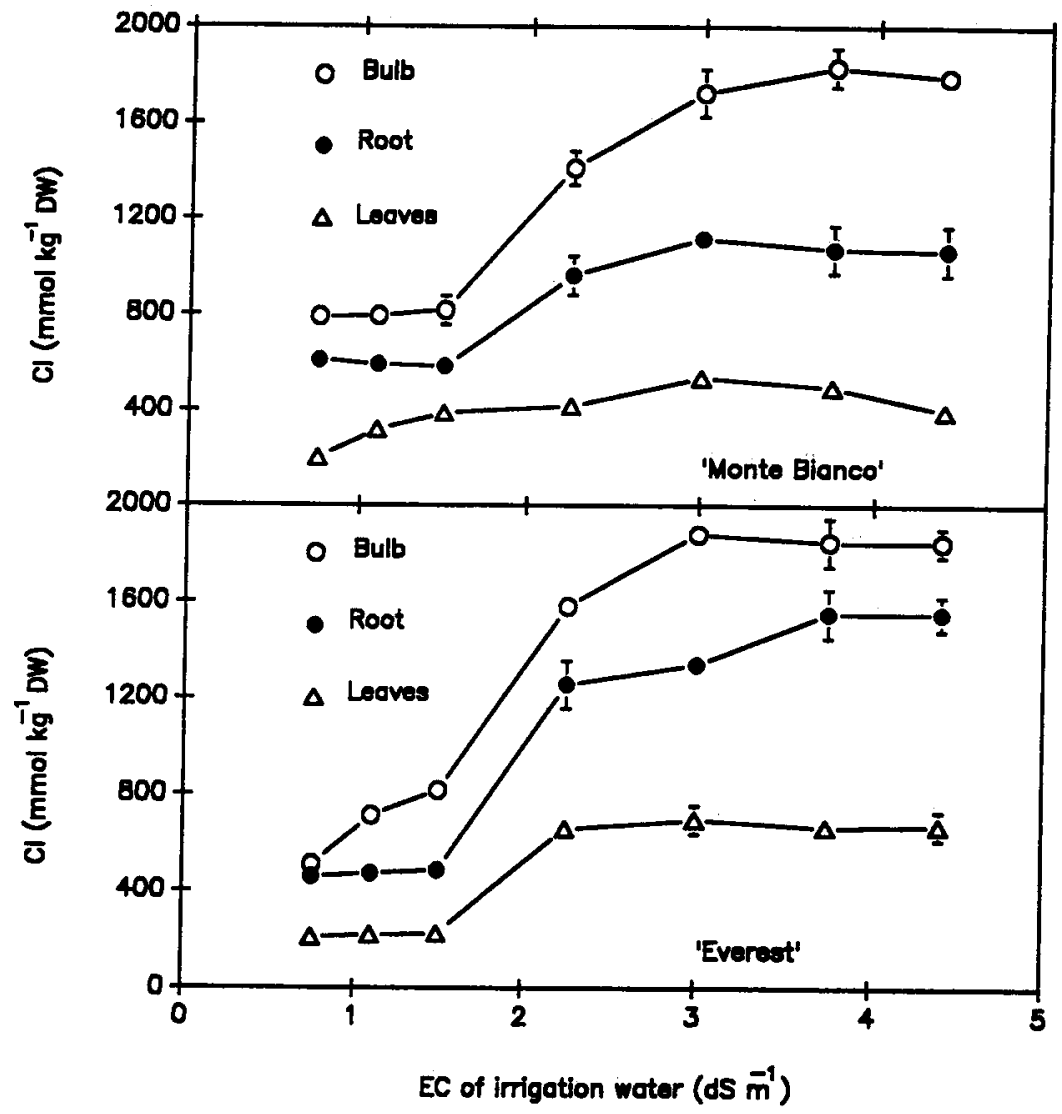

Fig. 4. Effects of electrical conductivity (EC) of irrigation water on $\mathrm{Cl}$ concentration in three plant tissues of two fennel cultivars. Vertical bars indicate standard error of the means. 


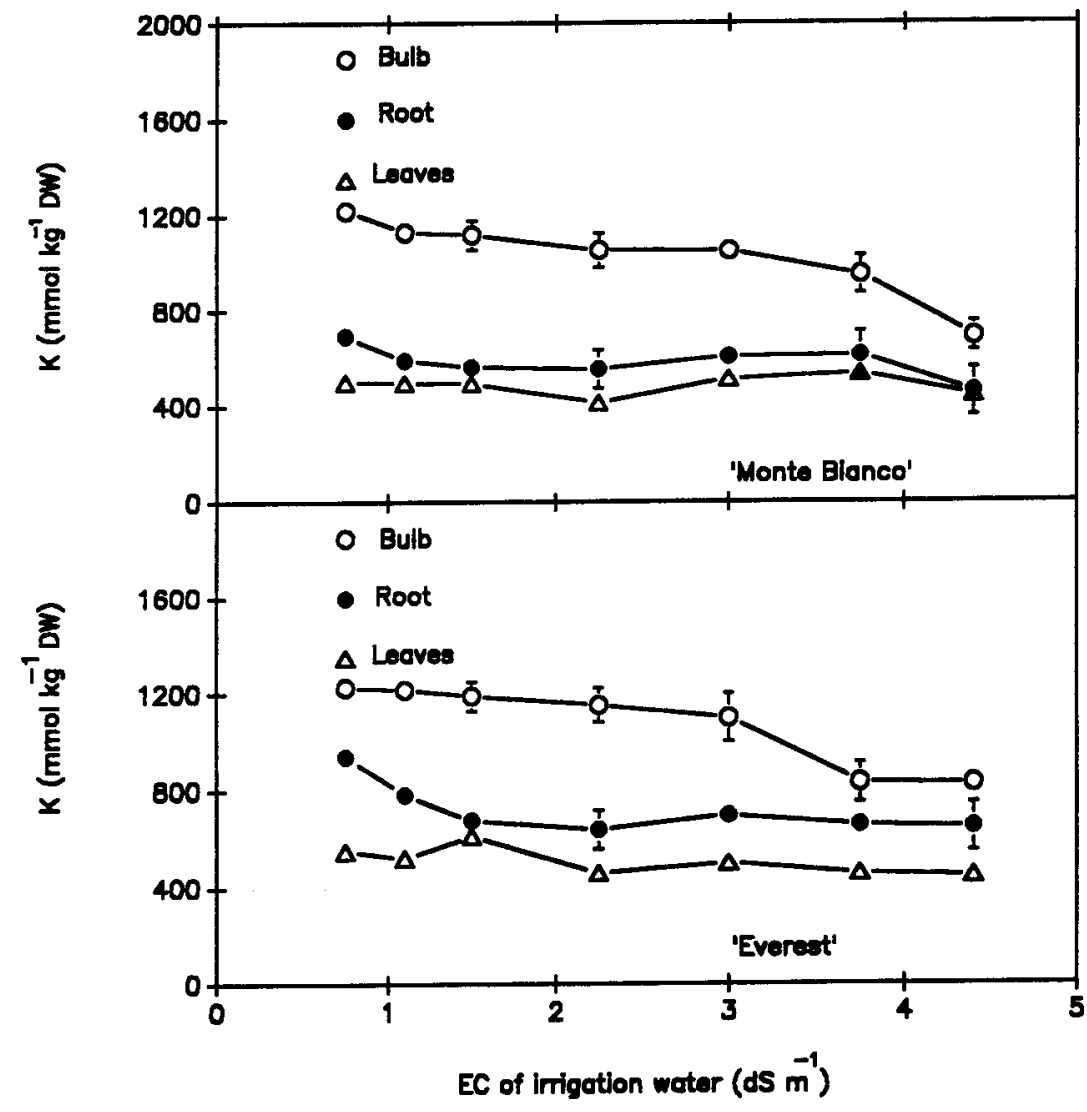

Fig. 5. Effects of electrical conductivity (EC) of irrigation water on K concentration in three plant tissues of two fennel cultivars. Vertical bars indicate standard error of the means.

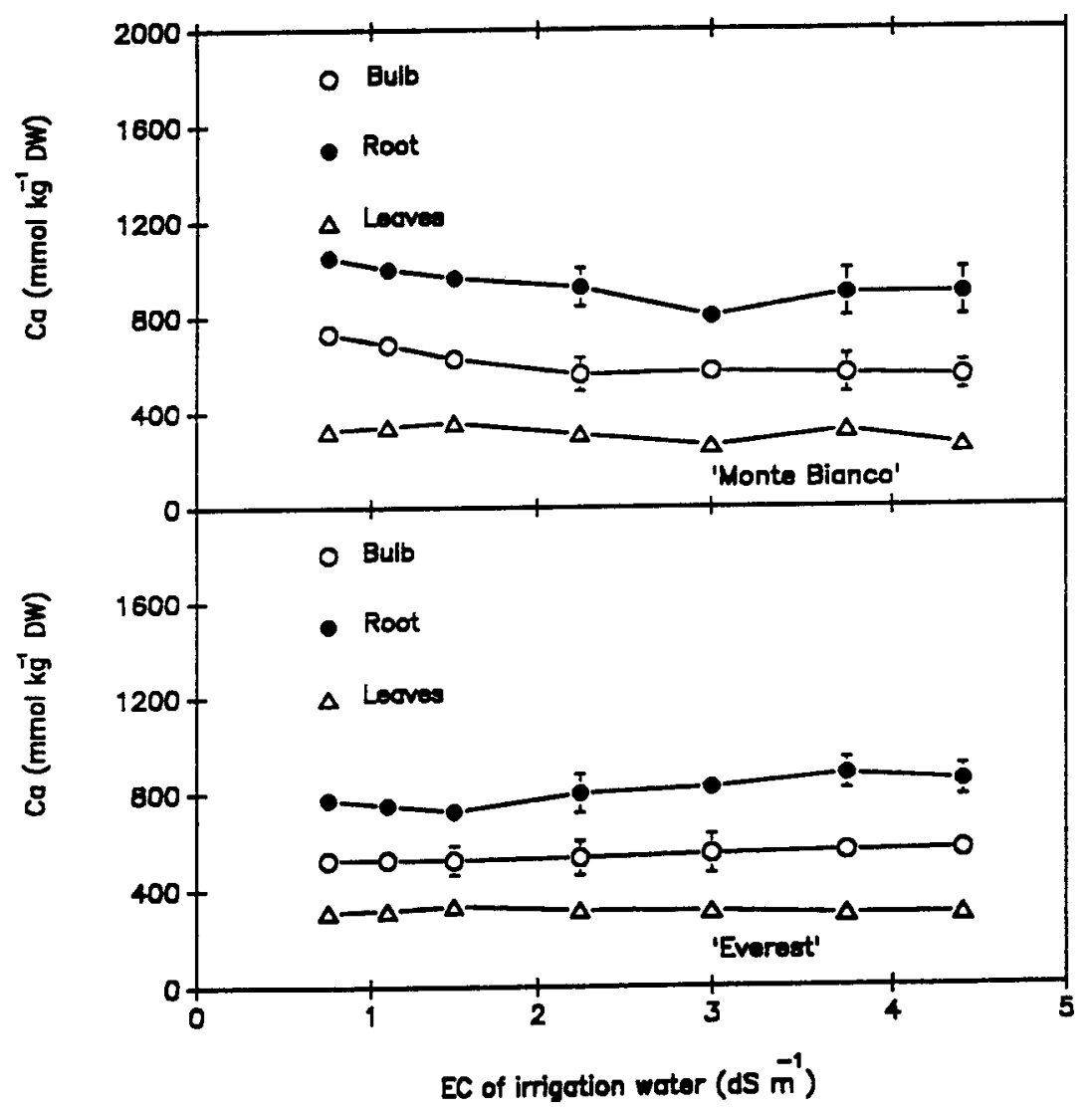

Fig. 6. Effects of electrical conductivity (EC) of irrigation water on Ca concentration in three plant tissues of two fennel cultivars. Vertical bars indicate standard error of the means. of many nonhalophytes. Since the bulb was the highest growth rate among fennel organs, the $\mathrm{K}$ deficiency may contribute to growth reduction because Kion influences the synthesis of organic compounds (Lauchli and Pfluger, 1978; Leigh and Wyn Jones, 1986).

Our results indicate that fennel is saltsensitive and has insufficient mechanisms to control salinity. Roots do not exclude salt uptake and do not retain the salt ions. Therefore, $\mathrm{Na}$ and $\mathrm{Cl}$ ions are transported directly to young tissue (the sheath), which is not capable of maintaining a low salt content in the cell cytoplasm.

\section{Literature Cited}

Cramer, G., E. Epstein, and A. Lauchli. 1989. Na-Ca interactions in barley seedlings: Relationship to ion transport and growth. Plant, Cell Environ. 12:551-558.

Dudley, L.M. 1994. Salinity in the soil environment, p. 1330. In: M. Pessarakli (ed.). Handbook of plant and crop stress. Dekker, New York.

Francois, L.E., T.I. Donovan, and E.V. Maas. 1991. Calcium deficiency of artichoke buds in relation to salinity. HortScience 26:549-553.

Graifenberg, A., L. Botrini, L. Giustiniani, and M. Lipucci Di Paola. 1996. Yield, growth and element content of zucchini squash grown under saline-sodic conditions. J. Hort. Sci. 71:305-311.

Graifenberg A., L. Giustiniani, O. Temperini, and M.Lipucci Di Paola. 1995. Allocation of $\mathrm{Na}, \mathrm{Cl}, \mathrm{K}$ and $\mathrm{Ca}$ within plant tissues in globe artichoke (Cynara scolymus L.) under saline-sodic conditions. Scientia Hort. 63:1-10.

Graifenberg A., M. Lipucci Di Paola, L. Giustiniani, and O. Temperini. 1993. Yield and growth of globe artichoke under saline-sodic conditions. HortScience 28:791793.

Greenway, H. and R. Munns. 1980. Mechanisms of salt tolerance in nonhalophytes. Annu. Rev. Plant Physiol. 31:149-190.

Istituto Nazionale di Statistica. 1995. Statistiche dell' agricoltura, zootecnia e mezzi di produzione. Ann. ISTAT 41:115.

Jandel Scientific. 1986. Sigma-Plot user's guide. release 2.1 ed. Jandel Scientific, S. Rafael, Calif.

Jeschke, W.D. 1984. $\mathrm{K}^{+}-\mathrm{Na}^{+}$exchange at cellular membranes, intracellular compartmentation of cations and salt tolerance, p. 37-66. In: R.C. Staples and G.H. Toenniessen (eds.). Salinity tolerance in plants: Strategies for crop improvment. Wiley, New York.

Lauchli, A. and E. Epstein. 1990. Plant responses to saline and sodic conditions, p. 113-117. In: K.K. Tanji (ed.). Agricultural salinity assessment and management. Manuals and reports on engineering practice. Amer. Soc. Civil Eng., New York.

Lauchli, A. and R. Pfluger. 1978. Potassium transport through plant cell membranes and metabolic role of potassium in plants. Proc. 11th Congr. Intl. Potash Inst. Bern, p. 111-163.

Leigh, R.A. and R.G. Wyn Jones. 1984. A hypothesis relating critical potassium concentrations for growth to the distribution and functions of this ion in the plant cell. New Phytol. 97:1-13.

Lynch, J. and A. Lauchli. 1984. Potassium transport in saltstressed barley roots. Planta 161:295-301.

Maas, E.V. and G.J. Hoffman. 1977. Crop salt tolerance. Current assessment. J. Irr. Drain. Div. 103:115-134.

Mangal, J. L., A. Yadava, and G.P. Singh. 1986. Effects of different levels of soil salinity on germination, growth, yield and quality of coriander and fennel. South Indian Hort. 34:26-31.

Munns, R. and A. Termot. 1986. Whole-plant responses to salinity. Austral. J. Plant Physiol. 13:143-160.

Zall, M.D., D. Fisher, and M.Q. Garner. 1956. Photometric determination of chlorides in water. Anal. Chem. 28:1655-1668 